\title{
Relevance of Further Education and Training College Engineering Learning Programmes within The Apprenticeship Context
}

\author{
Johannes Vusumuzi Zwane \\ Vaal University of Technology \\ Jhalukpreya Surujlal \\ North-West University (Vaal Triangle Campus) \\ Manilall Dhurup \\ Vaal University of Technology
}

Doi:10.5901/mjss.2014.v5n23p990

\begin{abstract}
The development of learning programmes and courses, qualifications design and future curriculum development in Further Education and Training (FET) vocational education provision on a national level is at the heart of the college sector. It should respond to the technological needs of labour market conditions, sectors and industries they support and more importantly, to the current critical South African economy. In this regard, apprenticeships have a huge role to play. This study was undertaken to identify factors, which were perceived as important in determining the relevance of FET college engineering learning programmes within an apprenticeship context. The sample in this study was 200 training and development managers, skills development facilitators and training practitioners with apprenticeship training responsibility and representing employers in the metal and engineering industry. A probability sampling technique in the form of simple random sampling was used to recruit participants for the study. Data were collected through the administration of a questionnaire. Descriptive statistics were used to report on the demographic data and exploratory factor analysis was conducted to identify factors that were perceived as important in determining the relevance of FET college engineering learning programmes. Four factors, namely meeting industry needs, industry-college alignment, context-focused learning, and industry collaboration were identified. In South Africa, FET colleges are expected to play an important role in the acquisition of human resource development (HRD) priority skills that are required by government and business to deliver on major infrastructure development and to meet the needs of an expanding economy.
\end{abstract}

Keywords: apprenticeship; engineering learning programmes; further education and training; FET colleges; learning pathways; metal and engineering sector; vocational education; work-based learning.

\section{Introduction and Background to the Study}

In an attempt to understand the vocational education provision in the FET college sector in South Africa and how it supports the metal and engineering industry apprenticeship system, the FET college's vocational education and its journey of transformation of provision in South Africa were undertaken. The origins, conceptual foundations, evolution and trajectory of the apprenticeship training system in South Africa and its performance are shaped profoundly by its historic inheritance from Britain (Akoojee, Gewer \& McGrath, 2005).

The first South African technical (FET) colleges were developed in the early twentieth century, administered under the 1923 Higher Education Act to provide theoretical learning alongside the practical or industrial training of the apprenticeship system (McGrath, 2004). Under this act, colleges were established to predominately play the central role in developing crucial intermediate skills for the economy (Umalusi, 2003).

The history of vocational education provision in South Africa has many different origins, and its development was informed by different contexts (McGrath, Badroodien, Kraak \& Unwin, 2004). The historical perspective reveals that from their earliest beginnings, technical and vocational education have included technical education, where it functioned as a foundation for practical knowledge, and vocational education referred to as forms of compensatory education with a practical aim (Gamble, 2003). Umalusi (2003, p. 19) defines vocational education as training "aimed at transferring competences and skills for specific occupations" and it is defined by its relationship to work life. 
The greatest challenge to the development of intermediate skills by FET colleges was mounted in the twentieth century (Cosser, McGrath, Badroodien \& Maja, 2003). Many of the newer FET colleges in South Africa date back to around this time when the 1980 Manpower Training Act was promulgated (Gamble, 2003).

Post-1994 democratic elections, the African National Congress (ANC)-led government continued with the programme of transforming the FET sector (Bird, 2001). Akoojee, McGrath and Visser (2008) state that the policy formulation in the post-apartheid configuration of the new FET college sector begun in 1996 with the appointment of the National Committee to investigate options for consolidating a fragmented FET college sector. Both the 1998 Education Green and White Papers on FET published concurrently, led to the drafting and promulgation of the 1998 FET Act, which laid out a vision for the college sector transformation (Fisher et al., 2003). This Act further provided for a greater institutional autonomy and financial control and, with the Department of Higher Education and Training (DHET) White Paper 4, broadened the mission and remit of the new FET college institutions (Fisher et al., 2003).

\section{Literature Review}

\subsection{The transition in apprenticeship in South Africa}

The apprenticeship training system has a long history in South Africa. According to Wedekind (2013), South African industrial training, which preceded provision of vocational education, can be linked directly to the system of slavery, rather than being an importation of the Middle Ages European tradition. A historical perspective shows that from its earliest beginnings industrial training focused on the imparting of skills in some form of handcraft, as well as the inculcation of discipline, obedience and regular work habits (Gamble, 2003). The term apprenticeship is Middle English from the Old French apprendre meaning to learn, to comprehend (Simeoni, 2003).

The earliest record of an apprenticeship contract in South Africa, which describes the relationship between master and apprentice, was signed on 18 August 1857 in Fort Beaufort in the Cape of Good Hope (Bird, 2001). Fifteen-year old Edward Henry James entered into a contract with Arthur Charles Gardiner to be apprenticed as a wheelwright (a person with the skills of the trade or craft to make or repair wooden wheels) for five years. James' contract reveals that it was very specific about duties and obligations and displayed most of the features traditionally associated with medieval apprenticeship contract in England and elsewhere (Gamble, 2004). In terms of his apprenticeship contract, the apprentice undertook to serve the master faithfully for the contract period, to obey his lawful commands and to keep his secrets. In return, the master undertook to instruct the apprentice in all aspects of the trade, to provide him with board and lodging and to pay him a set wage that would increase in each subsequent year of the apprenticeship (Gamble, 2004).

Apprenticeship, as a metaphor, still appears modern and useful in today's world, but the actual practice is considered antiquated (Perlin, 2011, p. 47). In response to social and economic trends, the apprenticeship-training programme has evolved to its present structure that includes a mix of on-the-job and classroom training focusing on the skills imbedded in a specific trade (McLaughlin, 2000).

\subsection{Learning pathways}

A learning pathway is a path or sequence of learning or experience than can be followed to attain competency. Its fundamental meaning is the creation or provision of the opportunity to progress from one state of learning to another (Ewing \& Donguet, 2007). This progression or movement is always in one direction and always moves from a lower state of learning to a higher state of learning. A description of some of the learning pathways follows.

\subsubsection{Coaching}

Coaching is fundamentally a learning relationship and a highly effective way to help people take charge of their own development, to release their potential and to achieve valued results (Connor \& Pokora, 2007). Serrat (2009) believes that coaching concentrates on the person and not the subject through talking, increased self-direction, self-esteem, efficacy and accomplishments. Coaching is effective primarily because it is a one-to-one method focussing on the needs and interests of the individuals (Martin, 2011).

\subsubsection{Job rotation}

Job rotation is the broadening of the background of trainees in an organisation, exposing the employees to wider range of 
experiences, and cross-training them (Singh \& Rawat, 2006). Bennett (2003) argues that learning gained through job rotation can be increased or accelerated by the use of coaching from the participant's manager, or from an experienced colleague in the host department or group. As the name suggests, job rotation, may involve no more than two individuals in different departments or functions, exchanging jobs for a limited period.

\subsubsection{Work-integrated training}

Streumer (2006) sums work-integrated training up as learning for work at work and through work. It is also referred as informal learning at work and regarded as being "a part of the job" or a mechanism of "doing the job properly" and is thus rendered invisible as learning (Boud \& Middleton, 2003). This misunderstanding of rendering learning invisible at work inevitably and unconsciously hampers work and the quality of work life.

\subsubsection{Understudy}

Understudying or job shadowing, also known as the attachment method, is a method that subjects an employee to onthe-job training in order that in future that employee can assume the full duties and higher responsibilities of the position currently held by the mentor (Kumar \& Mittal, 2001). Tatum (2011) argues that the act of job shadowing may also constitute an element of internship. It involves spending a period of time with a seasoned expert, observing everything that he/she does that is related to the work that is expected to be accomplished as part of the daily routine of the job.

\subsubsection{Internship}

Sweitzer and King (2009) refer to internship as the culminating academic experience in a highly structured and sequenced set of experiences. It provides the opportunity to gather and apply much of what one has learnt. What makes an internship worthy of the name is not how the time is arranged, but how the time is used, and the quality of the reflection, application of previous learning and other forms of critical thinking that are included.

\subsubsection{Apprenticeship}

Gamble (2003) states that the apprenticeship system is the best-known way of linking formal knowledge (education) and workplace experience, which is viewed as important as it helps employers to match potential workers to the workplace. The principal feature of apprenticeship implementation is that it is led by employers through their collective determination of the contents of apprenticeship in different sectors (Cassels, 2001).

\section{Modern Apprenticeships}

New state-led traineeship versions of the occupational or work pathway have been introduced across the world since the 1980s to replace the old apprenticeship system in a number of countries (Young \& Gamble, 2006). These learnerships, the new South African modern apprenticeships since the 2000s, are a critical topic in the FET sector, today, but are not part of this study. In the modern apprenticeships in the UK in 1994, and the South African equivalent of the modern apprenticeships, the learnerships were built on a long tradition of craft apprenticeships, and sought to extend the approach to emerging sectors and a wider range of occupations (Pember \& Pascoe, 2004). They have become the recognised route into skilled employment in many occupations, industries, and sectors. In 2009, a German study found that 40 per cent of young people who had the opportunity to attend university free of charge nonetheless chose instead to enter apprenticeships instead (Perlin, 2011). Whether learnerships will be a more effective route to skills acquisition remains to be proved.

\subsection{Purpose of apprenticeships}

As a longstanding practice of the schoolwork transition, apprenticeship has been described in various ways (Simeoni, 2003). Gamble (2004) explains that apprenticeships came with trades, in the sense that they provided apprentices with an opportunity to work under the close supervision of an artisan or journeyman, in all facets of a trade. An apprenticeship scheme allows for a controlled on-the-job training, workplace experience and institutionally based education training at the college. Apprentices are expected to demonstrate competence at each stage of a structured apprenticeship-training 
route and are required to pass regular tests (Lundall, 1997).

\subsection{Phasing out of apprenticeships}

There are many reasons that prompted the phasing out of apprenticeships in South Africa. The general decline of apprenticeships is but one of the issues that has become a matter of grave concern. Zehendes (2000) confirms that the number of learners in South Africa passing through apprenticeship system has consistently dropped over time. A result of the drop in the number of apprenticeship is the loss of training places for the rising numbers of FET learners who have successfully completed their college theoretical education. According to De Louw (2009), in contrast, apprenticeships were specific to artisan training (blue-collar trades), learnerships are built on the strengths of apprenticeships through the integration of workplace and institutional learning but cover a wide spectrum of sectors and occupations.

\section{Problem Statement}

A strong perception emerged that the current South African FET engineering programmes and qualifications are not highly regarded by employers due to the lack of DHET investment to update their curricula and content (Umalusi, 2003). In response to this the government decided to overhaul the FET curriculum in 2007 (Akoojee, 2008).

The evidence of the United Kingdom (UK) experience, as described by Young and Gamble (2006), suggests that programmes based solely on competence or unit standards such as the National Vocational Qualifications (NVQs) in the UK, and the South African equivalent of the NQVs, the NC(V) qualifications are not consistent with broader changes in the occupational structure. As a result, in South Africa the DHET has done an about-turn with the re-introduction of the NATED courses in 2010. Consequently, the apprenticeship system still exists parallel to the learnership route as a recognised learning pathway for qualifying as an artisan (Mummenthey, 2008, p. 27). This implies that only indentured learners (registered as apprentices) by industry are enrolled on the NATED courses and the other FET engineering learners are enrolled on the NC(V) learning programmes (RSA 2010, p. 4).

The relevance of the current FET curricula in meeting the skills needs that are required by industry has been a topic of much debate, as the South African NATED courses are viewed by key stakeholders as outdated (Young \& Gamble, 2006, p. 101). Despite the specific role FET colleges play in providing vocationally oriented education and training, their current learning programmes indicate a clear predominance of theory to the exclusion of practical experience in a workplace and work-based application (Gower, 2009, p. 1). In some respect, the FET qualifications and programmes lack quality, are often out dated, and in many cases have lost credibility (Umalusi 2003, p. 56).

The South African metal and engineering employers view the theory-based engineering learning pathway offered by colleges as not supporting the apprenticeship system and not relevant to the needs of the industry. In support of the aforementioned view, Ball $(1990$, p. 72) points out that the training establishments such as colleges generally maintain and perpetuate a bias towards academic learning to the disadvantage of practical or vocational education. With these challenges in mind the following objectives were developed.

\section{Purpose of the Study}

The purpose of the study was to identify factors, which were perceived as important in determining the relevance of FET college engineering learning programmes within an apprenticeship context.

\section{Methodology}

\subsection{Sample}

The sample in this study was 200 training and development managers, skills development facilitators and training practitioners with apprenticeship training responsibility and representing employers in the metal and engineering industry. A probability sampling technique in the form of simple random sampling was used to recruit participants for the study.

\subsection{Instrument}

The perceptions of the sample regarding the relevance of apprenticeships and colleges' vocational education provision of major industry role-players were explored through the administration of a questionnaire to the identified sample. Section 
A requested demographic information and background of the respondents pertaining to designation, years of service in the apprenticeship training role and types of apprenticeship training provided by the organisation. In Section $\mathrm{B}$, the perceptions of respondents regarding the relevance and appropriateness of FET college engineering programmes and qualifications were requested. A five-point Likert scales, ranging from strongly disagree to strongly agree were used. Items were scored as follows: strongly disagree=1; disagree=2; moderately agree=3; agree=4; strongly agree=5.

\subsection{Data analysis}

Descriptive statistics were used to report on the demographic data and exploratory factor analysis was conducted to identify factors, which were perceived as important in determining the relevance of FET college engineering learning programmes.

\subsection{Ethical considerations}

The researcher employed the following code of ethics during the study. Every respondent was informed of the purpose of the study. The researcher requested permission from the organisation to allow the participants to complete the questionnaire. The researcher assured the right to privacy, anonymity and confidentiality to each respondent who participated in the survey. An acknowledgement was forwarded to each respondent who participated in the survey upon receipt of a completed questionnaire.

\section{Results}

\subsection{Demographic information}

The majority respondents (30\%) were training and development managers. Eight $(7 \%)$ respondents were skills development managers, $23(19 \%)$ technical training managers respondents and 20 (17\%) were skills development facilitators respondents. $46(38 \%)$ respondents had between one to five years of service in the apprenticeship role, 21 $(18 \%)$ had between six to ten years, $12(10 \%)$ had between 11 to 15 years and 16 to 20 years of service respectively, and $29(24 \%)$ had over 20 years of service. An overview of the trades provided through apprenticeships by the respondents reflects that the majority of trades provided through apprenticeships were electricians, fitters, millwrights and boilermakers. Riggers and turners comprised the smallest numbers of trades provided through apprenticeships.

Of the respondents, 107 (89\%) within the metal and engineering sector were member companies with the Steel and Engineering Industries Federation of South Africa (SEIFSA), and the other 13 (11\%) were non-members.

\subsection{Exploratory factor analysis}

The Bartlett's test of sphericity was conducted and the Kaiser-Meyer-Olkin (KMO) measure of sampling adequacy was undertaken to establish whether the data was suitable for a factor analysis. The Kaiser-Meyer-Olkin (KMO) measure of sampling adequacy was 0.87 (a value deemed meritorious by Kaiser $(1974$, p. 35)) and the Bartlett's test of sphericity was significant at 0.000 indicating that factor analysis could be conducted on the captured data. Principal component analysis together with Varimax rotation was applied to all the items in Section B of the questionnaire to identify factors, which were perceived as important in determining the relevance of FET college engineering learning programmes within an apprenticeship context. The final factor structure comprised four factors, namely meeting industry needs, industrycollege alignment, context-focused learning and industry collaboration. The rotated component matrix is presented in Table 1. 
Table 1: Rotated factor loading matrix

\begin{tabular}{|c|c|c|c|c|}
\hline \multirow{2}{*}{ Factor and variable descriptions } & \multicolumn{4}{|c|}{ Factors } \\
\hline & 1 & 2 & 3 & 4 \\
\hline \multicolumn{5}{|l|}{ Meeting industry needs (Factor 1 ) } \\
\hline FET vocational programmes deliver learners with skills and competencies that employers need. & 0.858 & 0.046 & -0.106 & 0.039 \\
\hline FET colleges supply the industry with a labour force that has the skills they need. & 0.832 & 0.350 & -0.072 & 0.003 \\
\hline Colleges produce a workforce with competencies required in industry. & 0.806 & 0.354 & 0.024 & 0.061 \\
\hline The FET curriculum meets industry needs. & 0.799 & 0.331 & -0.029 & -0.117 \\
\hline Colleges provide good quality vocational education for occupationally-directed skills employment. & 0.795 & 0.298 & 0.075 & 0.030 \\
\hline FET college programmes increase the pool of skilled and semi-skilled workers. & 0.794 & 0.094 & -0.035 & 0.129 \\
\hline $\begin{array}{l}\text { The FET curriculum exposes learners broadly on all aspects of occupationally-directed career } \\
\text { development. }\end{array}$ & 0.769 & 0.153 & -0.041 & -0.001 \\
\hline FET college programmes increase the employability of their learners. & 0.751 & 0.124 & -0.091 & 0.131 \\
\hline The current FET curriculum is aligned adequately with the world of work. & 0.734 & 0.228 & 0.101 & 0.194 \\
\hline FET learning programmes meet the technological needs and skills required in the workplace. & 0.715 & 0.424 & -0.149 & -0.095 \\
\hline College programmes offer practical, work experience aligned to work placement. & 0.695 & 0.442 & -0.089 & 0.104 \\
\hline The FET college curriculum has a theory-practice balance. & 0.677 & 0.130 & -0.089 & -0.216 \\
\hline FET sector produces the required number of skilled learners and semi-skilled workers for the industry. & 0.675 & 0.292 & -0.010 & 0.070 \\
\hline FET curriculum focuses on on-the-job learning. & 0.673 & 0.424 & 0.210 & 0.082 \\
\hline The new national certificate vocational (NCV) college curriculum develops learners for employment. & 0.663 & 0.085 & 0.112 & 0.165 \\
\hline FET curriculum makes provision for the on-the-job learning. & 0.652 & 0.150 & -0.192 & 0.256 \\
\hline FET college programmes and qualifications are practical in nature. & 0.640 & 0.366 & -0.046 & -0.030 \\
\hline \multicolumn{5}{|l|}{ Industry - college alignment (Factor 2) } \\
\hline FET colleges assess customer needs to design their curriculum. & 0.265 & 0.854 & 0.026 & 0.134 \\
\hline FET colleges conduct environment analysis closely attuned to the needs of their stakeholders. & 0.357 & 0.803 & -0.174 & -0.040 \\
\hline FET colleges monitor labour market trends to assess the needs of their stakeholders. & 0.434 & 0.744 & 0.147 & 0.009 \\
\hline \multicolumn{5}{|l|}{ Context - focused learning (Factor 3) } \\
\hline Workplace learning is the authentic environment for skills acquisition and situation-specific competence. & -0.128 & -0.127 & 0.806 & 0.089 \\
\hline Occupational training and context-specific work experience is the primary focus in apprenticeship. & 0.033 & -0.053 & 0.764 & 0.183 \\
\hline $\begin{array}{l}\text { Apprenticeship combines classroom-based learning with work-based experiences to support the } \\
\text { development of occupational skills. }\end{array}$ & -0.025 & 0.160 & 0.697 & -0.149 \\
\hline \multicolumn{5}{|l|}{ Industry collaboration (Factor 4 ) } \\
\hline Business-college partnerships act as catalyst for sustainable change in vocational education. & 0.098 & 0.202 & 0.068 & 0.904 \\
\hline Business-college partnerships strengthen and develop the FET sector and system. & 0.081 & 0.057 & 0.046 & 0.889 \\
\hline Eigenvalue & 11.73 & 2.19 & 1.70 & 1.37 \\
\hline$\%$ of variance explained & 46.91 & 8.75 & 6.80 & 5.47 \\
\hline Cumulative $\%$ & 46.91 & 55.66 & 62.46 & 63.93 \\
\hline Reliability (Cronbach alpha) & 0.96 & 0.87 & 0.66 & 0.84 \\
\hline Means & 2.394 & 2.714 & 3.242 & 3.819 \\
\hline
\end{tabular}

\section{Discussion}

The primary objective of this study was to identify factors, which were perceived as important in determining the relevance of FET college engineering learning programmes within an apprenticeship context. The following factors were perceived to be important.

\subsection{Factor 1: Meeting industry needs}

Factor 1, meeting industry needs, comprised 17 variables and accounted for 46.9 percent of the variance explained. The metal and engineering industry apprenticeship role-players deemed meeting the needs of industry to be one of the most important colleges' curriculum challenges faced by the FET sector. A curriculum is a scheme for fitting together bits of knowledge. As the bits of knowledge are connected in the curriculum so they enter the minds of the learners, and though the details of the content will fade, the connections are likely to guide their judgements and perpetuate the system of 
power that the curriculum represents (Ensor, 2002). Young and Gamble (2006) believe that the vocational education curriculum involves two steps in the recontextualisation of disciplinary knowledge. Usually, the first is undertaken by members of professions, such as engineers and managers who transform the sciences into applied sciences or technologies that take account of the specific needs of different types of manufacture and service. The second step is the pedagogic recontextualisation that takes into account what can be taught and to whom; ex-professionals who specialise in teaching usually undertake this. Recontextualisation refers to the appropriation and transformation of knowledge for various purposes (Young \& Gamble, 2006).

Simeoni (2003) states that occupational training is the primary focus in apprenticeships while employment experiences are carefully blended with the vocational educational objectives in institutional learning programmes. Vocational education is organised into courses, which take place in FET colleges and tend to play a complementary role to instruction in the workplace, concentrating on relevant theory underlying individual trades (West \& Steedman, 2003). Young and Gamble (2006) add that application of scientific knowledge required in apprenticeships is left to apprentices and employers, and not included in the FET college tuition.

\subsection{Factor 2: Industry-college alignment}

Factor 2, interpersonal relationships, comprised three variables and accounted for 8.8 per cent of the variance explained.

Perold, Cloete and Papier (2012) are of the opinion that building common links or strategic partnerships by FET colleges to business and industries can be used by colleges for planning, in order to meet particular provincial, regional or community needs. Through a thorough analysis of the college environment, the government (DHET) must also conduct specific labour and education market trends and needs to determine and assist the FET colleges to offer relevant and responsive learning programmes to the needs of the economy (DoE 2006). For a far reaching and sustainable change in the vocational education and industrial training system within the South African context a modern, high quality responsive public FET system contribution significantly to accelerated and expanded skills development delivery, and improved quality of skills in required (National Business Initiative, 2007.

\subsection{Factor 3: Context-focused learning}

Factor 3, context-focused learning, consisted of three variables, which accounted for 6.8 per cent of the variance. The balancing act relationship between theory and workshop practice at the colleges is a feature of certain types of vocational systems (Gamble, 2004). In support of this view, Young and Gamble (2006) indicate that college-based vocational qualifications are not sufficiently practical and on their own do not seem to lead to employment.

If apprenticeship training for skills acquisition has been implemented successfully, it was in particular where "systematic acquisition of theoretical knowledge and gradual build-up of experiential knowledge" are intertwined (Lutz, 1994). Workplace experience is necessary yet, in itself, is not sufficient to allow a grasp of the concepts from which general principles are obtained (McGrath et al., 2004).

Young and Gamble (2006) maintain that vocational pedagogy, the content and process of vocational learning and teaching, are influenced on the one hand by workplace activities and on the other hand by disciplinary knowledge. Workplace experience and workshop training are crucial to vocational preparation but they do not both serve the same function (Gamble, 2003). Workshop training assists in the transmission of general principles (trade theory), while workplace learning, on the other hand teaches the procedures of a particular workplace and situation-specific competence.

According to McGrath (2004), by the start of the 1990s the linkages of the college's theoretical learning with apprenticeship had radically declined as colleges enrolled increasing numbers of non-apprentices into their programmes. This meant that practical learning no longer complemented the theoretical provision of the colleges for the majority of learners. Therefore, a major challenge was to find a mechanism to ensure that college programmes become relevant and responsive and that the skills acquired are transferred and applied successfully in the workplace. Reforming the South African FET curriculum will attempt to remove much criticism in the recent years of the old-and-too-far removed learning engineering programmes from the needs of industry as generally perceived by many stakeholders (Akoojee et al., 2008).

\subsection{Factor 4: College-industry collaboration}

Factor 4, college-industry collaboration, comprised two variables, which accounted for 5.5 per cent of the variance explained. In keeping with the Human Resource Development strategy of South Africa (HRD-SA), with regards to the key 
strategic objective of "increasing employer participation in lifelong learning", the government expects employers to align themselves with, and assist the efforts of government to strengthen and develop the FET sector by having direct participation of commerce and industry, and playing a key role in the products of the colleges (DoE \& DoL, 2002).

The business community through Business Unity South Africa (BUSA) also believes that business-education partnerships are a vital step forward in providing realistic vocational options and ensuring that the FET curriculum is aligned with the needs of business (Ntuli, 2007). Too few employers in South Africa have seen their local colleges as a vital partner or have taken a proactive stance in supporting these FET colleges' institutions (McGrath, 2004). There were 1852 linkages or joint partnership projects between colleges and industry, non-governmental organisations and government in 2002, of which 52 per cent of the linkages were with business (Akoojee et al., 2008).

\section{Limitations of the Study}

The findings of this study should be viewed in the light of its limitations. The fact that the study consisted of respondents from only one industry, the metal and engineering sector was a significant limitation of this study. This was as a result of the scope of the study. The financial and time constraints as well as the logistical problems of the study also contributed to the limitations that resulted in the exclusion of the other industries in the sample. While the sampling technique and sample size are consistent with similar studies conducted on the FET college-sector curriculum, generalisation of the findings should be approached with caution.

\section{Concluding Remarks}

In South Africa, FET colleges are expected to play an important role in the acquisition of human resource development (HRD) priority skills that are required by government and business to deliver on major infrastructure development and to meet the needs of an expanding economy. The current study identified the factors, which are deemed to be important in assessing the relevance of FET colleges engineering learning programmes in the context of apprenticeships. It is, therefore, important for developers of curricula to integrate this in their planning.

\section{References}

Akoojee, S. (2008). FET college lecturers: the "devolving" link in the South African skills development equation. Journal of Vocational Education and Training, 60(3), 297-313.

Akoojee. S., Gewer, A., \& McGrath, S. (2005). Vocational education and training in Southern Africa. Cape Town: HSRC Press. [Online] Available:<http://hsrcpress.ac.za/product.php?cat=8\&sort=title\&sort_direction=\&page=6\&freedownload=1\&productid-2078> (May 17, 2008).

Akoojee. S., McGrath, S., \& Visser, M. (2008). Human Sciences Research Council, Human Resource Development Review 2008-Chapter 12: education, employment and skills in South Africa-further education and training colleges. Cape Town: HSRC Press. [Online] Available: $<$ http://www.hsrcpublishers.ac.za/product.php?productid=2218\&cat=0\&page=1\&feature\&freedownload=1> (January 11, 2008).

Ball, J. (1990). Flexibility and complexity, opening the black box of training. [Online] Available: <http://www.avetra.org.au/ ABSTRACTS2006/PA\%200059.pdf> (September 11, 2009).

Bennett, B. (2003). Job rotation: Its role in promoting learning in organisations. Journal of Development and Learning in Organisations, 17(4), 7-9.

Bird, A. (2001). National monograph on technical and vocational training in South Africa. International Labour Organisation (ILO) report for the Human Resource Development recommendation and skills and employability. Geneva. ILO. [Online] Available: $<$ http://www.llo.org.public/english/employment/skills/hrdr/publ/006.htm> (November 07, 2008).

Boud, D., \& Middleton, H. (2003). Learning from others at work: Communities of practice and informal learning. Journal of Workplace Learning, 15(5), 194-202.

Cassels, J. (2001). The way to work-modern apprenticeships: The report of the modern apprenticeship advisory committee. [Online] Available: http://www.employersforapprentices.gov.uk/docs/research/Research_1_97.pdf (March 30, 2009).

Connor, M., \& Pokora, J. (2007). Coaching and mentoring at work: Developing effective practice. New York: The McGraw-Hill.

Cosser, M., McGrath, S., Badroodien, A., \& Maja, B. (2003). Training colleges responsiveness: Learner destinations and labour market environments in South Africa. Cape Town: HSRC Press. [Online] Available: http://www.hsrcpublishers.ac.za (July 26, 2007).

De Louw, L. A. 2009. Efficacy of learnership programmes: an exploratory investigation of learner perceptions in the Cape Peninsula. MTech. Thesis. Human Resource Management. Cape Town: Cape Peninsula University of Technology.

DoE see Republic of South Africa. Department of Education.

DoL see Republic of South Africa. Department of Education \& Department of Labour.

Ensor. P. (2002). Exploring typologies of curriculum design-chapter 8: Curriculum in "transformation in higher education-global pressures and local realities in South Africa. Lansdowne: Juta \& Co. Pty (Ltd). [Online] Available: <http://www.chet.org.zal webfm_send/285> (November 09, 2011).

Ewing, J., \& Donguet, J. (2007). Part II: Learning pathways and design of integrated learning tools. [Online] Available: $<$ http://www.hal/archivesouverles.fr/docs/00/30/54/56/PDF/cahier_0701.pdf> (September 11, 2008). 
Gamble J. (2003). Curriculum responsiveness in FET colleges. Cape Town: HSRC Press. [Online] Available: http://hsrcpress.ac.za/ user_uploads/tblPDF/1945_00_Curriculum_Responsiveness-in-FET-Colleges-21012005025201PM.pdf (July 26, 2007).

Gamble, J. (2004). Tacit knowledge in craft pedagogy: a social analysis. DPhil Thesis. School of Education, Graduate School of Humanities. Cape Town: University of Cape Town.

Gower, P. (2009). "Outdated" technical courses to return. Mail \& Guardian. [Online] Available: <http://www.mg.co.za/article/2009-12-04- outdatedtechnical-courses-to-return> (August 17, 2010).

Kaiser, H. F. (1974). An index of factorial simplicity. Psychometrika, 39, 31-36.

Kumar, N., \& Mittal, R. (2001). Personnel management and industrial relations. New Delhi: Anmol Publications.

Lundall, P. 1997. The erosion of apprenticeship training in South Africa's metal and engineering industry. M Soc. Thesis. Cape Town: University of Cape Town.

Lutz, R. (1994). Apprenticeship training on employment. Germany: Hamburg.

Martin, G. (2011). Competing through management. [Online] Available: <http://www.glennmartin.com.au/coachmentor.htm> (October 03, 2011).

McGrath, S. (2004). Reviewing the development of the South African further education and training college sector ten years after the end of apartheid. Journal of Vocational Education and Training, 56(1), 137-160.

McGrath. S., Badroodien, A., Kraak, A., \& Unwin, L. (2004). Shifting understanding of skills in South Africa. Cape Town: HSRC Press. [Online] Available: http://hsrcpress.ac.za/product.php?productid=2040\&freedownload=1 (May 17, 2008).

McLaughlin, L. M. (2000). Flexibility and mobility in apprenticeship training. MA Thesis. Economics. University of Manitoba.

Mummenthey, C. (2008). Implementing efficient and effective learnerships in the construction industry: A study on the learnership system in the building and civil sector of the Western Cape. M Comm Thesis. Human Resources. University of Stellenbosch.

National Business Initiative. (2007). Case study 6: Partnerships in education - the college industry program. Johannesburg. [Online] Available: <http://www.nbi.org.za/Lists/Publications/Attachments/37/CIP\%20Case\%20Studt.2008.pdf> (December 11, 2007).

Ntuli, D. (2007). Business has a plan to help create jobs. Sunday Times, p. 40, 27 May.

Pember. S., \& Pascoe, K. (2004). 21st century apprenticeships: end to end review of the delivery of modern apprenticeships. Cape Town: HSRC Press. [Online] Available: <http://www.employersforapprentices.gov.uk/docs/research/Reseach_1_251.pdf> (May 03, 2011).

Perlin. R. (2011). How to earn nothing and learn little in the brave new economy. New York: Verso. [Online] Available: <http://books. google.co.za/books?id=yFBZ9IfTrDwC\&printsec=frontcover\&source=gbs_ge_summary_r\&cad=0\#v=onepage\&q\&f=false> (May 15 , 2013).

Perold, H., Cloete, N., \& Papier, J. (2012). Shaping the future of South African's youth: Rethinking post school and skills training. Sommerset West: African Minds.

Republic of South Africa. (2010). Amendment to Government Notice 1200 in Gavernment Gazette No. 32810, dated 14 December 2009 , regarding the extension of the offering of National N Certificates: N4-N6. Government Gazette, 405, 1-4, 17 May. (Regulation Gazette No.33201).

Republic of South Africa. Department of Education. (1998). Green Paper on: Further education and training: preparing for the $21^{\text {st }}$ century through education, training and work. Pretoria: Government Printer.

Republic of South Africa. Department of Education. (2000). National Curriculum Framework for Further Education and Training. Pretoria: Government Printer.

Republic of South Africa. Department of Education \& Department of Labour. (2002).Human Resources Development Strategy for South Africa: A nation at work for a better life for all. Pretoria: Government Printer.

Republic of South Africa. Department of Education. (2005). White Paper on proposed new funding norms for FET colleges. Pretoria: Government Printer.

Republic of South Africa. Department of Education. (2006). Draft guideline for learning programme development for FET colleges. Pretoria: Government Printer.

Republic of South Africa. (1998). Skills Development Act (97 of 1998). Pretoria: Government Printer.

Serrat. O. (2009). Coaching and mentoring. [Online] Available: http://www.adb.org/documents/information/knowledge-solutions/ coaching-andmentoring.pdf (July 15, 2011).

Simeoni, G., N. (2003). The apprenticeship training and cooperative education in British Columbia. PhD Thesis. Comparative Education. Pretoria: University of South Africa.

Singh, Y. K., \& Rawat, H. S. (2006). Human resource management. New Delhi: A P H Publishing Corporation.

Streumer, J. N. (2006). Work-related learning. The Netherlands: Springer.

Sweitzer. F., \& King, M. A. (2009). The successful internship: personal, professional and civic development. (3rd ed.). United States of America: Cengage Learning. [Online] Available: http://books. Google.co.za/books?id=7_V5AsErqwsC\&printsec=frontcover \&source=gbs_ge_summary_r\&cad=0\#v=onepage\&q\&f=false (May 15, 2013).

Tatum. M. (2011). What is job shadowing. [Online] Available: http://www.wisegeek.com/what-is-job-shadoowing.htm (August 16, 2011).

Umalusi. (2003). The organisation of qualifications in the further education and training band: Current thinking and possibilities. Pretoria. [Online] Available: http://www.umalusi.org.za/ur/research/Qualifications\%20in\%20 FET\%20Band.pdf (August 23, 2007).

Young, M., \& Gamble, J. (2006). Knowledge, curriculum and qualifications for South African further education. Cape Town. HSRC Press. [Online] Available: http://www.hsrcpress.ac.za (March 02, 2010).

West, J., \& Steedman, H. (2003). Finding our way: Vocational education in England. England: London School of Economics and Political Science.

Wedekind, V. (2013). Rearranging the furniture? Shifting discourses on skills development and apprenticeship in South Africa. A Paper presented to the International Network on Innovative Apprenticeship at the $5^{\text {th }}$ conference of the Apprenticeship in a Global World: Premises, Promises and Pitfalls held in the University of the Witwatersrand. Johannesburg.

Zehendes, W. (2000). Networking with partners. [Online]. Available: http://www.Inweb90.worldbank.org/CAW/ Cawdoclib.nsf/ vewBestPractices/83F45367DD75765FF85256CF50068207E/\$file/Networking_with_partners_2000.pdf (August 31, 2011). 